\title{
PLASMA VOLUME OF DOGS IN DEHYDRATION, WITH AND WITHOUT SALT LOSS ${ }^{1}$
}

\author{
By JAMES HOPPER, JR.,2 J. RUSSELL ELKINTON, ${ }^{3}$ \\ AND ALEXANDER W. WINKLER \\ (From the Department of Internal Medicine, Yale University School of Medicine, New Haven)
}

(Received for publication July 2, 1943)

Severe chronic water deprivation in the dog produces surprisingly little peripheral circulatory failure (1). This type of dehydration results in a contraction of extracellular fluid volume without any considerable sacrifice of extracellular salt. On the other hand, dehydration of somewhat comparable severity, in which salt as well as water is lost, may regularly be followed by acute circulatory collapse (2). From the published experiments, it is not clear whether this greater susceptibility of the circulation in the salt depleted animal is simply a quantitative matter, depending on a greater contraction of extracellular fluid and of plasma volumes, or whether it depends as well on the qualitative change in the composition of the body fluids. In the present experiments, reductions in body water were brought about, both with and without accompanying salt loss. The resulting changes in extracellular fluid volume, in plasma volume, and in the state of the circulation were then compared.

\section{MATERIAL AND METHODS}

The chemical methods used and the methods of calculating changes in the extracellular and intracellular distribution of water have been described elsewhere $(1,3)$. Plasma volume was determined by two independent methods. In the first, the volume of distribution of the blue dye, T-1824, 10 minutes after intravenous injection, was assumed equal to the plasma volume. In the second, the volume of distribution of a known volume of inhaled carbon monoxide, after 20 minutes, was assumed equal to the whole blood volume. Relative cell volume of anaerobically defibrinated whole blood was then determined in calibrated Daland hematocrit tubes (4). Plasma volume was calculated from the whole blood volume. Details of both methods are to be published elsewhere $(5,6)$.

\footnotetext{
1 Aided by grants from the Fluid Research Fund of Yale University, the Ella Sachs Plotz Fund, and the John and Mary R. Markle Foundation.

2 Alexander Brown Coxe Fellow, 1941-42.

American College of Physicians Fellow, 1942-43.

3 National Research Council Fellow in the Medical Sciences, $1940-42$.
}

Adult female dogs were used throughout. Intake and output of water, chloride, sodium, potassium, and nitrogen were measured. At suitable intervals, measurements of plasma volume were made, and changes in extra- and intracellular fluid volume calculated from the weight changes and chloride balances. In Experiments 11A, $11 \mathrm{~B}, 12 \mathrm{~A}$, and $12 \mathrm{~B}$, the changes in extracellular fluid volume were also measured directly by the distribution of sulfocyanate and radioactive chloride and sodium, the results of which are reported in another paper (7). In one group of chronic experiments, 2 dogs were first subjected to 12 days of water deprivation and fasting (Experiments $11 \mathrm{~A}$ and $12 \mathrm{~A}$ ). After rehydration and refeeding, the dogs were rested for a month. They were then subjected to an acute depletion of sodium chloride by withdrawal of peritoneal fluid following previous intraperitoneal injection of an isotonic glucose solution (Experiments $11 \mathrm{~B}$ and $12 \mathrm{~B}$ ). This was followed by water deprivation and fasting for 3 days. Finally, the salt and water contents of the animals were restored to normal. These 4 experiments permitted a comparison of the effects of water deprivation with and without salt depletion in the same animals. In Experiment 22B, the procedure was varied somewhat. Here the animal, in addition to simple dehydration, was subjected to progressive depletion of salt by the peritoneal route. The results could be compared with those in control animals in whom there was no such additional salt loss (1).

Four acute experiments were performed. In 2 of them (Experiments 23A and 26A), 10 per cent urea in 5 per cent glucose solution was injected intraperitoneally, and an equivalent volume of peritoneal fluid was withdrawn some 4 hours later. This resulted not only in salt depletion, but in the absorption of a great deal of urea into the system as well. During the next few hours, this absorbed urea stimulated a marked diuresis, so that there gradually developed a large net depletion of water in excess of that of salt. The 2 other experiments (25A and 26B) served as controls, since no urea was injected with the glucose and hence no diuresis with consequent water depletion developed.

Criteria of circulatory status. Three classes of criteria were employed. (a) Direct measurements of plasma volume were made by two independent methods, and the changes in plasma volume in turn could be compared with changes in serum protein concentration and in relative cell volume ${ }^{4}(6)$. Since a decline in plasma

4 Changes in relative cell volume reflect changes in the base concentration of the plasma, as well as changes 
TABLE I

Exchange of water, electrolytes, and nitrogen

\begin{tabular}{|c|c|c|c|c|c|c|c|c|c|c|c|c|}
\hline \multirow{2}{*}{ Procedure } & \multirow{2}{*}{$\begin{array}{c}\text { Experi- } \\
\text { ment }\end{array}$} & \multirow{2}{*}{$\begin{array}{l}\text { Time from } \\
\text { start of } \\
\text { experiment }\end{array}$} & \multicolumn{5}{|c|}{ Net intake } & \multicolumn{5}{|c|}{ Urinary output } \\
\hline & & & $\mathrm{H} \_\mathrm{O}$ & $\mathrm{Na}$ & $\mathrm{Cl}$ & $\mathbf{K}$ & $\mathbf{N}$ & $\mathrm{H} \& \mathrm{O}$ & $\mathbf{N a}$ & $\mathrm{Cl}$ & $\mathbf{K}$ & $\mathbf{N}$ \\
\hline $\begin{array}{l}\mathrm{H}_{2} \mathrm{O} \text { depriv.* } \\
\text { Oral } \mathrm{H}_{2} \mathrm{O} \\
\text { Re-feeding }\end{array}$ & $11 \mathrm{~A}$ & $\begin{array}{c}\text { days } \\
12 \\
14 \\
26\end{array}$ & \begin{tabular}{c|}
$c c$. \\
-15 \\
$1079 \#$ \\
$6224 \#$
\end{tabular} & $\left|\begin{array}{r|}m . e q . \\
-\quad 3.7 \\
-\quad 2.8\end{array}\right|$ & $\begin{array}{c}\text { m. eq. } \\
0.5 \\
-\quad 1.1 \\
587.3 \$\end{array}$ & $\begin{array}{l}\text { m. eq. } \\
339.3 \#\end{array}$ & $\begin{array}{c}\text { grams } \\
114.1 \#\end{array}$ & $\begin{array}{c}c c . \\
880 \\
567 \\
2440\end{array}$ & $\begin{array}{r}m . e q . \\
75.8 \\
3.1\end{array}$ & $\begin{array}{r}m . e q . \\
62.2 \\
7.4 \\
547.0\end{array}$ & \begin{tabular}{r|} 
m. eq. \\
130.0 \\
4.0 \\
249.0
\end{tabular} & $\begin{array}{l}\text { grams } \\
35.0 \\
4.5 \\
89.3\end{array}$ \\
\hline $\begin{array}{l}\mathrm{NaCl} \text { deplet. } \ddagger \\
\mathrm{NaCl} \text { restor.8॥ }\end{array}$ & 11B & $\begin{array}{l}3 \\
4\end{array}$ & $\begin{array}{r}164 \\
1110\end{array}$ & $\begin{array}{r}-107.8 \\
152.7\end{array}$ & $\begin{array}{r}78.1 \\
154.2\end{array}$ & -2.8 & -0.2 & $\begin{array}{l}225 \\
515\end{array}$ & $\begin{array}{r}9.3 \\
38.0\end{array}$ & $\begin{array}{r}8.1 \\
51.1\end{array}$ & $\begin{array}{l}16.5 \\
36.2\end{array}$ & $\begin{array}{l}6.2 \\
6.4\end{array}$ \\
\hline $\begin{array}{l}\mathrm{H}_{2} \mathrm{O} \text { depriv. } \\
\text { Oral } \mathrm{H}_{2} \mathrm{O} \\
\text { Re-feeding }\end{array}$ & $12 \mathrm{~A}$ & $\begin{array}{l}12 \\
14 \\
26\end{array}$ & $\begin{array}{l}-9 \\
1013 \# \\
6345 \#\end{array}$ & $=\begin{array}{ll}- & 3.7 \\
- & 1.6\end{array} \mid$ & $\begin{array}{c}0.5 \\
-\quad 0.4 \\
554.8\end{array}$ & $321.6 \#$ & 113.6\# & $\begin{array}{r}620 \\
205 \\
1510\end{array}$ & $\begin{array}{r}70.8 \\
5.9\end{array}$ & $\begin{array}{r}55.6 \\
9.6 \\
506.0\end{array}$ & $\begin{array}{r}111.2 \\
7.4 \\
229.0\end{array}$ & $\begin{array}{r}29.5 \\
4.8 \\
53.0\end{array}$ \\
\hline $\begin{array}{l}\mathrm{NaCl} \text { deplet.‡ } \\
\mathrm{NaCl} \text { restor.\| }\end{array}$ & 12B & $\begin{array}{l}3 \\
4\end{array}$ & $\begin{array}{r}41 \\
1405\end{array}$ & $\begin{array}{r}-113.0 \\
152.8\end{array}$ & $\begin{array}{r}-93.9 \\
154.2\end{array}$ & -4.3 & -0.2 & $\begin{array}{l}340 \\
700\end{array}$ & $\begin{array}{l}19.8 \\
36.6\end{array}$ & $\begin{array}{l}30.4 \\
37.0\end{array}$ & $\begin{array}{l}30.2 \\
33.2\end{array}$ & $\begin{array}{l}3.6 \\
9.1\end{array}$ \\
\hline $\begin{array}{l}\mathrm{NaCl} \text { deplet. } \neq \\
\mathrm{H}_{2} \mathrm{O} \text { depriv. } \\
\mathrm{H}_{2} \mathrm{O} \text { depriv. } \\
\mathrm{NaCl} \text { deplet. } \\
\mathrm{H}_{2} \mathrm{O} \text { depriv. }\end{array}$ & 22B & $\begin{array}{l}0.2 \\
2 \\
4 \\
5 \\
8\end{array}$ & $\begin{array}{r}120 \\
-16 \\
-36 \\
136 \\
-39\end{array}$ & $\begin{array}{lr}- & 95.6 \\
= & 1.8 \\
= & 4.7 \\
= & 39.5 \\
- & 5.5\end{array}$ & $\begin{array}{rr}= & 77.9 \\
= & 1.1 \\
= & 3.3 \\
= & 34.2 \\
- & 3.3\end{array}$ & $\begin{array}{l}-2.4 \\
-0.9\end{array}$ & $\begin{array}{l}-0.13 \\
-0.09\end{array}$ & $\begin{array}{r}30 \\
460 \\
95 \\
97 \\
190\end{array}$ & $\begin{array}{l}0.5 \\
3.2 \\
4.2 \\
3.1 \\
0.9\end{array}$ & $\begin{array}{l}0.5 \\
4.0 \\
1.3 \\
1.1 \\
3.2\end{array}$ & \begin{tabular}{r|}
2.1 \\
12.0 \\
29.3 \\
17.4 \\
31.7
\end{tabular} & $\begin{array}{r}0.90 \\
7.36 \\
5.97 \\
5.01 \\
14.78\end{array}$ \\
\hline $\begin{array}{l}\mathrm{NaCl} \text { deplet. } \ddagger \\
\mathrm{H}_{2} \mathrm{O} \text { deplet. (urea) }\end{array}$ & $23 \mathrm{~A}$ & $\begin{array}{l}0.3 \\
1\end{array}$ & $\begin{array}{r}3 \\
-28 \\
\end{array}$ & $\begin{array}{r}52.8 \\
-\quad 4.0 \\
\end{array}$ & $\begin{array}{r}-42.7 \\
-\quad 2.7 \\
\end{array}$ & -1.2 & 19.02 & $\begin{array}{l}340 \\
400\end{array}$ & $\begin{array}{l}0.5 \\
1.0\end{array}$ & $\begin{array}{l}2.2 \\
4.1\end{array}$ & $\begin{array}{r}3.3 \\
20.5\end{array}$ & $\begin{array}{r}7.01 \\
12.10\end{array}$ \\
\hline $\begin{array}{l}\mathrm{NaCl} \text { deplet. } \neq \\
\mathrm{H}_{2} \mathrm{O} \text { deplet. (urea) }\end{array}$ & $26 \mathrm{~A}$ & $\begin{array}{l}0.2 \\
1\end{array}$ & $\begin{array}{r}65 \\
-72\end{array}$ & & $=\begin{array}{r}35.2 \\
-\quad 8.2\end{array}$ & -0.9 & 21.71 & $\begin{array}{l}525 \\
500\end{array}$ & & $\begin{array}{l}8.8 \\
1.0\end{array}$ & $\begin{array}{r}6.5 \\
30.9\end{array}$ & $\begin{array}{r}8.27 \\
16.90 \\
\end{array}$ \\
\hline $\begin{array}{l}\mathrm{NaCl} \text { deplet. } \\
\text { Oral } \mathrm{H}_{2} \mathrm{O}\end{array}$ & $25 \mathrm{~A}$ & $\begin{array}{l}0.3 \\
1\end{array}$ & $\begin{array}{r}103 \\
-42\end{array}$ & $\begin{array}{r}-77.8 \\
-\quad 4.8 \\
\end{array}$ & $\begin{array}{r}-\quad 63.8 \\
-\quad 3.1\end{array}$ & -2.8 & -0.12 & $\begin{array}{r}23 \\
245 \\
\end{array}$ & $\begin{array}{l}0.3 \\
0\end{array}$ & $\begin{array}{l}0.6 \\
1.2\end{array}$ & $\begin{array}{l}2.0 \\
4.5\end{array}$ & $\begin{array}{l}0.52 \\
1.46\end{array}$ \\
\hline $\mathrm{NaCl}$ deplet. $\ddagger$ & 26B & 0.3 & -9 & -156.0 & -145.0 & -2.8 & -0.17 & 265 & 4.1 & 9.3 & 4.1 & 0.72 \\
\hline
\end{tabular}

* Abbreviation for deprivation.

$\dagger$ Abbreviation for depletion.

$¥$ By intraperitoneal injection of glucose solution and subsequent withdrawal of peritoneal fluid.

Abbreviation for restoration.

By intravenous injection of saline solution.

\# Oral intake (food consisted of "Maro" meat mixture; for analysis see (3), EXPERIMENTAL PROCEDURE).

In both tables time from start of experiment indicates end of period, at which time serum analyses were made and balances determined. Quantities are expressed per individual period rather than cumulatively. In designation of experiment, number refers to the individual dog; where a dog was used more than once, letter refers to successive experiments.

volume regularly accompanies the development of peripheral circulatory failure, these measurements gave indirect information concerning the status of the circulation. (b) Observation of the femoral pulse and estimations of the rate of venous return from the extremities, as well as the general condition of the animal, gave direct evidence of the dynamic state of the circulation. These observations were qualitative rather than quantitative. Only great weakness or actual disappearance of the femoral pulse was considered indicative of a dynamically inadequate circulation. Likewise, only virtual inability to obtain blood in any quantity by puncture of the femoral or jugular veins was considered evidence of diminished return. (c) In experiments lasting a number of hours, the concentration of non-protein nitrogen in the blood in its volume. Allowance for this fact was made wherever necessary. serves as a rough measure of the average functional adequacy of the renal circulation during the period in question. It should be noted that the dynamic criteria serve only to distinguish severe circulatory impairment, and that moderate restriction of circulatory competence might escape detection.

\section{RESULTS}

The experimental results are presented in Tables I and II. Simple deprivation of food and water (Experiments $11 \mathrm{~A}$ and $12 \mathrm{~A}$ ) affected the distribution of water and of electrolytes in a manner which has previously been described (1). Volumes of both intracellular and extracellular phases diminished to about the same degree. 


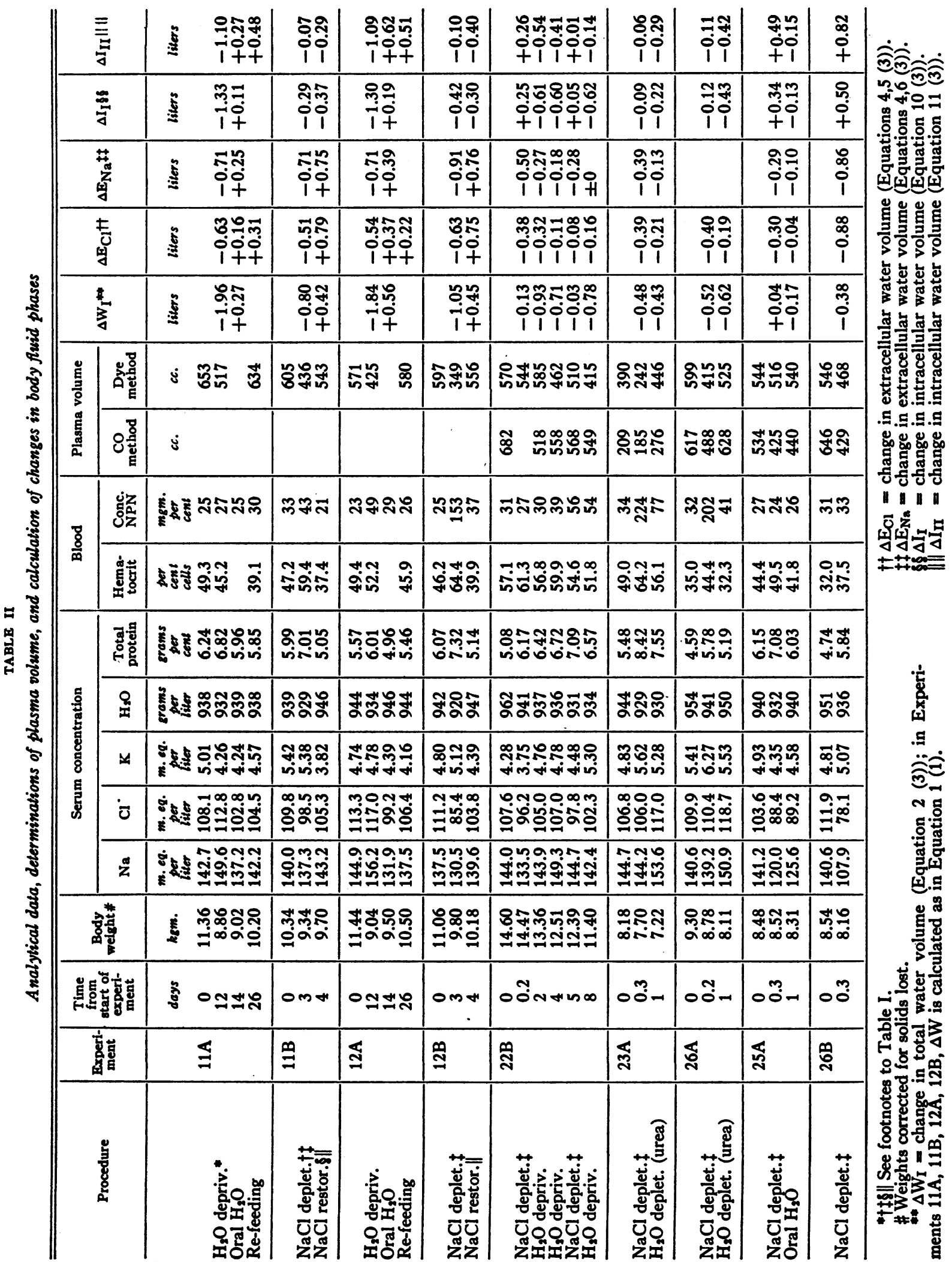


Total ionic concentration in body fluids rose above normal. At the end of the period, the circulation was clinically almost unimpaired. Blood nonprotein nitrogen concentration was unchanged in $11 \mathrm{~A}$ and rose only slightly in $12 \mathrm{~A}$. However, the plasma volume, here measured by the dye method alone, was reduced by 21 per cent in one dog and by 26 per cent in the other. Serum protein concentration and relative cell volume changed relatively little. The stability of the latter may have resulted from a balance between the contraction of cells due to hypertonicity and the tendency of the relative cell volume to increase with decreasing plasma volume, or to an actual decrease in the total circulating red cell mass. All these changes in fluid distribution were reversed when fluid and food were restored.

Depletion of salt and water resulted in quite a different picture in the same 2 dogs (Experiments $11 \mathrm{~B}$, and 12B). Loss of water was mainly extracellular, and total ionic concentration of the body fluids fell. Intracellular fluid declined a little, since osmotic transfer of water into the cells did not quite compensate for that lost with protein breakdown. There was no "excess" loss of potassium ( $b_{\mathbf{K}^{\prime}}$ ) over and above that to be expected from tissue breakdown alone (3). Both dogs were listless and weak, the pulses became weak and thready, blood was difficult to obtain by venepuncture, and blood non-protein nitrogen increased significantly. In both dogs, the changes in relative cell volume and in serum protein concentration exceeded those developing during the period of water depletion alone. The plasma volumes decreased 28 per cent and 42 per cent, respectively. In one dog, the decrease in plasma volume was only a little greater than that following water depletion alone, while in the other, it was much more marked. In both dogs, the evidences of circulatory inadequacy were all much more marked with salt depletion than without it. Injection of hypertonic salt solution and free drinking of water at the close of the experiment caused a re-expansion of the extracellular phase and of the plasma volume. During this period of restoration, there was a loss of potassium in excess of nitrogen, in spite of the net positive water balance. The significance of this has been discussed elsewhere (3).

The dog subjected to chronic water and food deprivation, together with progressive depletion of sodium chloride (Experiment 22B), died in the tenth day of the experiment. This was a shorter period of survival than that of control animals, deprived of food and water alone (In addition to the 2 control experiments described here, 4 have been reported previously (1)). Death occurred in spite of the fact that the total water loss (27 per cent) was less than that of the control animals. Water was lost from both phases of body water, but that from the extracellular fluid was proportionately greater. The dog appeared weak and listless, pulse was thready, venous blood flow was poor, and the blood non-protein nitrogen concentration was elevated. However, the final plasma volume was only moderately reduced, 19 per cent by one method and 26 per cent by the other. This reduction was no greater than that found without associated circulatory inadequacy in simple water deprivation (Experiments 11A, and 12A). The body fluids of this animal became chronically hypotonic, in contrast to the hypertonicity of the animals with simple water deprivation.

In 2 experiments (23A and 26A), in which urea administration was combined with salt depletion, there were 2 phases of reaction. In the first, salt depletion predominated, resulting in a transient hypotonicity with a moderate decrease in extracellular volume. Plasma volume also fell sharply. In the second phase, water loss exceeded salt loss, due to a diuresis induced by urea. Intracellular fluid volume decreased markedly and extracellular fluid volume continued to decline. As a result, the body fluids now became hypertonic. Despite the further dehydration, plasma volume returned to normal.

In the initial phase of 2 control experiments (25A and 26B), in which salt depletion was induced without subsequent water depletion, the diminution of extracellular fluid volume and the hypotonicity of body fluids were accompanied by a fall in plasma volume. Only 1 animal survived for a period corresponding to the second phase of Experiments $23 \mathrm{~A}$ and $26 \mathrm{~A}$. In this phase, the body fluids remained hypotonic and the intracellular volume was larger than normal. The behavior of the plasma volume was indeterminate since, as measured by one technique, it rose, but, as measured by another, it remained depressed. 


\section{DISCUSSION}

The view has been widely held that loss of sodium chloride is harmful mainly because it leads to a reduction in the volume of the extracellular fluid $(8,2)$. This is based on the fact that, under many circumstances, loss of extracellular water does tend to parallel that of extracellular salt. It is assumed that this reduction of extracellular volume leads in turn to a proportional contraction of plasma volume, with consequent impairment of normal circulatory dynamics. Our experiments indicate that this simple conception can be only partially correct. Were the reduced volume of the extracellular fluid wholly responsible for the adverse effects on the circulation, the manner in which the reduction was effected would be immaterial. Such is not, however, the case. For example, in Figure 1, the circulatory responses of Dog 12 to simple water deprivation and to loss of salt and water are compared. The decline in extracellular fluid volume was about the same with both procedures. Nevertheless, plasma volume was strikingly reduced and circulatory efficiency much impaired following salt withdrawal, effects which were absent with simple severe water loss. Here, obviously, changes in volume of extracellular fluid alone do not explain these differing circulatory reactions.

Clinical experience supports the importance to the circulation of composition as well as of vol-

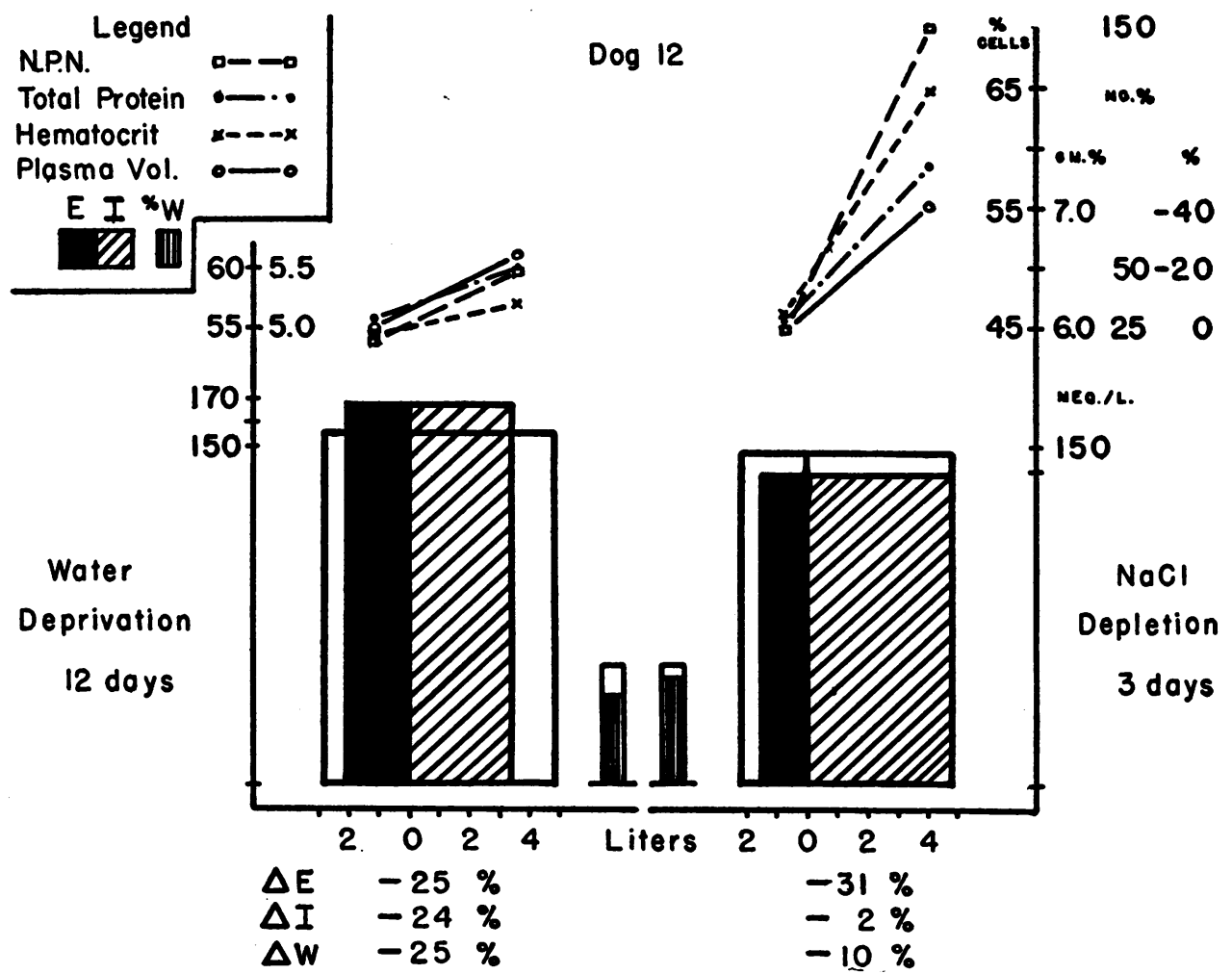

Fig. 1. Comparison of the Effects on the Plasma Volume and on the Circulation of Dehydration With Salt Depletion (right hand figure), and Without Salt DepleTION (LEFT HAND FIGURE)

The volumes of the extracellular (E) and intracellular (I) phases are plotted along the abscissae, while the total base concentrations are plotted along the ordinates. Areas, therefore, represent total amounts of electrolyte. The initial patterns are shown in outline, the final patterns in solid black and cross-hatching. Initial and final values for plasma volume, hematocrit, total protein, and non-protein nitrogen concentrations are plotted linearly. Percentage changes of different phases are given under the figure; $\Delta \mathrm{E}, \Delta \mathrm{I}$, and $\Delta \mathrm{W}$ refer to changes in extracellular, in intracellular, and in total water volumes, respectively. Total water (W) is represented graphically by the small vertically-ruled colums between the two large diagrams. 


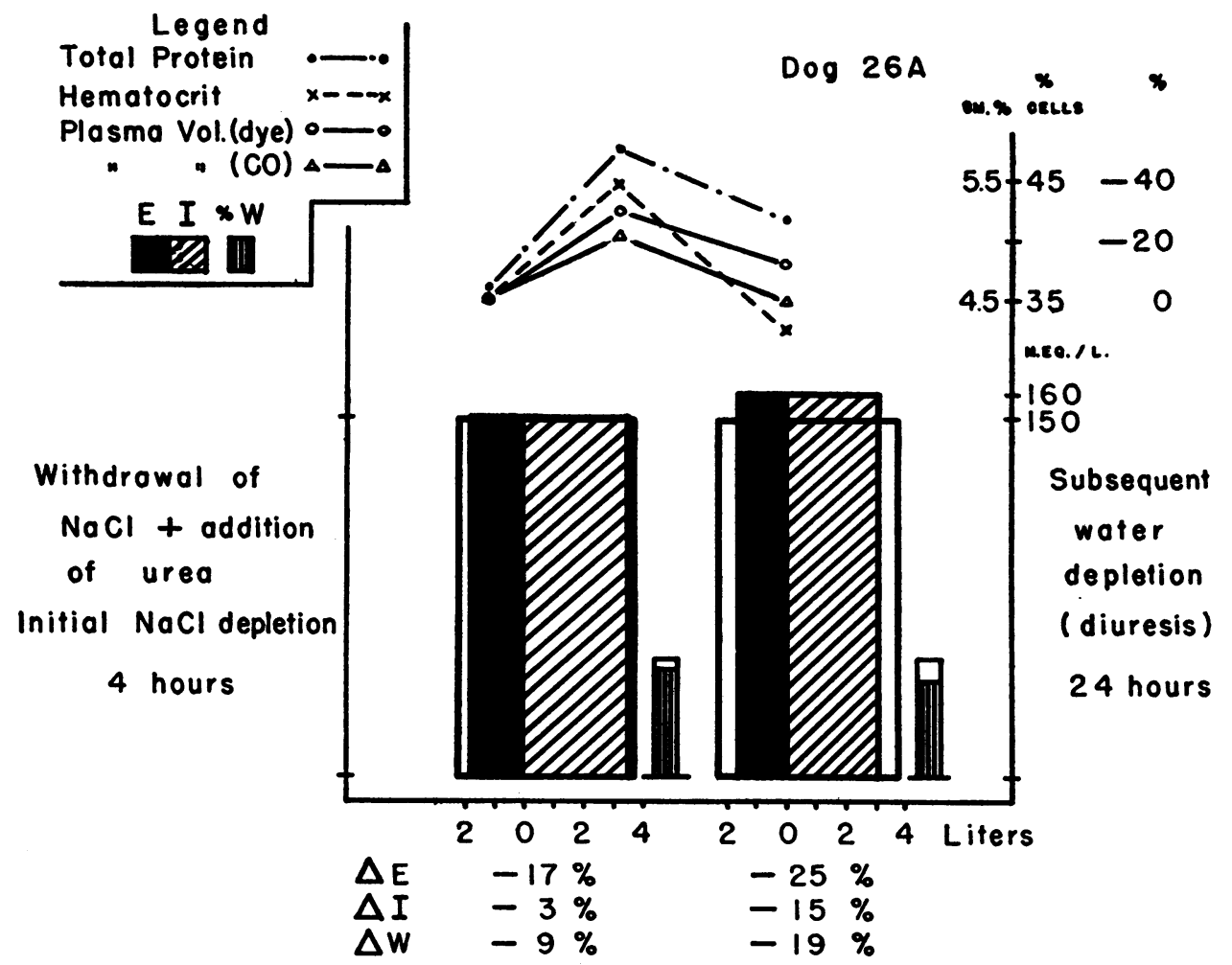

Fig. 2. The Effect on the Composition and Distribution of Body Fluids, on the Circulation, and on the Plasma Volume, of Initial Depletion of Salt and Subsequent Depletion of Water (Experiment 26A)

Diagrams are similar to those in Figure 1, except that the body fluid pattern is represented at the end of the first period of 4 hours and again at 24 hours.

ume of the extracellular fluid (9). Parenteral administration of pure dilute glucose solutions to patients with shock associated with salt depletion tends to intensify rather than to alleviate the circulatory impairment. This is true in spite of the fact that such glucose solutions do effect some expansion of extracellular volume. The expansion is, however, effected at the price of a further dilution of extracellular electrolyte.

Extracellular fluid volume per se is evidently only one of the factors affecting plasma volume, and is not necessarily the most important one. Examples of dissociation between changes in volume of the extracellular fluid and changes in plasma volume may easily be found. Thus, the plasma volume of Dog 22B tended to increase on 2 occasions, although loss of extracellular fluid was progressive throughout the experiment. Plasma volume increased while the extracellular salt content of the body decreased in various other experiments, such as $22 \mathrm{~B}, 23 \mathrm{~A}$, and $26 \mathrm{~A}$. Instead, contraction and subsequent reexpansion of plasma volume in the face of continued decline in the volume of the extracellular fluid is shown in Figure 2 (Experiment 26A). There is clearly a marked spontaneous tendency for the plasma volume to return to normal, even in the absence of sufficient water or salt.

Although peripheral circulatory failure was always associated with a sharp reduction in plasma volume, the converse of this proposition is not necessarily true. With simple dehydration, the plasma volume may be considerably reduced without rise in blood non-protein nitrogen or other distinct evidence of circulatory failure (Experiment $11 \mathrm{~A}$ ). It is probably mainly a question of the degree of contraction, since, even in this animal, a slightly greater contraction of plasma volume induced by combined water and salt depletion did result in some rise in the blood nonprotein 
nitrogen (Experiment 11B). Granting that the contraction of plasma volume is the same, it is not clear that the circulation in the salt-depleted animal is functionally less adequate than that of the animal with simple water loss. There is certainly much to suggest that hypotonicity is harmful only in so far as it may favor a reduction in plasma volume. In Experiment 25A, for example, the circulation in the hypotonic animal seemed to be dynamically adequate so long as plasma volume was maintained. Conversely, there is little indication that increase in tonicity per se is responsible for improvement of plasma volume, since a rising plasma volume is as often accompanied by a fall in sodium of serum as by a rise (Table II).

\section{CONCLUSIONS}

(1) Changes in plasma volume parallel those in extracellular fluid volume only under certain limited conditions.

(2) Depletion of extracellular salt and water results in a more severe circulatory embarrassment than can be attributed to the contraction in extracellular fluid volume alone.

The authors wish to thank Dr. Samuel Harvey for the use of the animal room of the Department of Surgery, and for the assistance of its staff.

\section{BIBLIOGRAPHY}

1. Elkinton, J. R., and Taffel, M., Prolonged water deprivation in the dog. J. Clin. Invest., 1942, 21, 787.

2. Nadal, J. W., Pedersen, S., and Maddock, W. G., A comparison between dehydration from salt loss and from water deprivation. J. Clin. Invest., 1941, 20, 691.

3. Elkinton, J. R., and Winkler, A. W., Transfers of intracellular potassium in experimental dehydration. J. Clin. Invest., 1944, 23, 93.

4. Eisenman, A. J., MacKenzie, L. B., and Peters, J. P., Protein and water of serum and cells of human blood, with a note on the measurement of red blood cell volume. J. Biol. Chem., 1936, 116, 33.

5. Hopper, J., Jr., and Tabor, H., Adaptation of the palladium method for the determination of carbon monoxide to the calculation of blood volume. To be published.

6. Hopper, J., Jr., and Winkler, A. W., The simultaneous determination of blood volume in man and dog by means of Evans blue dye, T-1824, and by means of carbon monoxide. To be published.

7. Winkler, A. W., Elkinton, J. R., and Eisenman, A. J., Comparison of sulfocyanate with radioactive chloride and sodium in the measurement of extracellular fluid. Am. J. Physiol., 1943, 139, 239.

8. Darrow, D. C., and Yannet, H., Metabolic studies of the changes in body electrolyte and distribution of body water induced experimentally by deficit of extracellular electrolyte. J. Clin. Invest., 1936, $15,419$.

9. Elkinton, J. R., Gilmour, M. T., and Wolff, W. A., The control of water and electrolyte balance in surgical patients. Ann. Surg., 1939, 110, 1050. 